\title{
Deteksi Posisi Plat Nomor Kendaraan Menggunakan Metode Transformasi Hough Dan Hit Or Miss
}

\author{
${ }^{1}$ Yuda Puspito, ${ }^{2}$ F. X. Arinto Setyawan, Helmy Fitriawan ${ }^{3}$ \\ ${ }^{1}$ Jurusan Teknik Elektro, Fakultas Teknik, Universitas Lampung \\ ${ }^{1}$ yudapuspito@gmail.com, \\ 2fx.arintodeng.unila.ac.id \\ sfitriawan@eng.unila.ac.id
}

Intisari - Penelitian ini dikembangkan sebuah sistem pendeteksi posisi plat nomor kendaraan yang ditampilkan pada GUI Matlab. Pendeteksian posisi plat nomor kendaraan menggunakan dua metode, yaitu metode transformasi hough dan transformasi hit or miss. Tahap pengolahan citra yang digunakan meliputi: binerisasi, aras keabuan, deteksi tepi, pemotongan citra, filtering, dan resizing. Keefektifan sistem ini diukur dengan perhitungan terhadap nilai perolehan (recall) dan nilai ketepatan (precision). Berdasarkan hasil penelitian didapatkan bahwa sistem berhasil mendeteksi posisi plat nomor kendaraan dengan tingkat keberhasilan pendeteksian sebesar $76 \%$ untuk nilai threshold $0,75,72 \%$ untuk nilai threshold 0,8 dan $48 \%$ untuk nilai threshold 0,85 . Hasil penelitian juga menunjukkan nilai rata-rata recall sebesar $54 \%$ untuk nilai threshold $0,75,50 \%$ untuk nilai threshold 0,8 dan $40 \%$ untuk nilai threshold 0,85 , sedangkan nilai rata-rata precision sebesar $14 \%$ untuk nilai threshold $0,75,14 \%$ untuk nilai threshold 0,8 dan $12 \%$ untuk nilai threshold $\mathbf{0 , 8 5}$.

Kata kunci - Trasnformasi Hough, Transformasi Hit Or Miss, Recall, Precission.

Abstract: This research was developed a detection system of vehicle license plates that displayed at the GUI Matlab. The detecting the number plate position of the vehicle uses two methods, namely the transformation method of hough and the transformation of hit or miss. The image processing stages used include: binerization, gray level, edge detection, image cutting, filtering, and resizing. The effectiveness of this system is measured by calculating the value of the recall and the precision. Based on the results of the study it was found that the system successfully detected the number plate position of the vehicle with a detection rate of $76 \%$ for the threshold value of 0.75 , $72 \%$ for the threshold value of 0.8 and $48 \%$ for the threshold value of 0.85 . The results also showed an average recall value of $54 \%$ for the threshold value of $0.75,50 \%$ for the threshold value of 0.8 and $40 \%$ for the threshold value of 0.85 , while the average value of precision was $14 \%$ for the threshold value of $0.75,14 \%$ for the threshold value of 0.85 , while the average value of precision was $14 \%$ for the threshold value of $0.75,14 \%$ for the threshold value of 0.8 and $12 \%$ for the threshold value of 0.85 .

Keywords: Trasnformasi Hough, Transformasi Hit Or Miss, Recall, Precission.

\section{PENDAHULUAN}

Saat ini kebutuhan manusia akan mobilitas atau kendaraan pribadi sudah menjadi kewajiban yang harus dipenuhi, baik mobilitas dari sepeda motor ataupun kendaraan beroda empat. Hukum Indonesia mewajibkan setiap kendaraan pribadi memiliki pengenal berupa plat nomor kendaraan. Pengenal kendaraan tersebut harus tercatat dalam database yang disimpan oleh pemerintah pusat [1]. Umumnya, pencatatan pengenal kendaraan dilakukan secara manual oleh petugas. Petugas menjumpai kendaraan yang akan dicatat, kemudian ditulis secara manual dalam buku.
Perkembangan teknologi saat ini dapat digunakan untuk membuat sistem pengenal plat nomor kendaraan otomatis berbantuan perangkat lunak komputer (software). Sistem pengenal tersebut diharapkan mampu menghemat waktu dan tenaga dalam melakukan pencatatan identitas kendaraan bermotor yang masih dilakukan secara manual.

Pada penelitian ini akan dibuat sebuah sistem pendeteksi posisi plat nomor kendaraan menggunakan software Matlab. Matlab merupakan perangkat lunak produk dari The MathWork, Inc. yang memadukan kemampuan perhitungan, pencitraan, dan pemrograman dalam satu paket [2]. Sistem 
dari matlab ini diharapkan mampu mendeteksi dan menunjukkan plat nomor kendaraan dari beberapa kendaraan yang tergambar dalam sebuah citra digital. Sistem ini menggunakan teknik-teknik pengolahan citra, seperti resizing, gray scaling, thresholding, edge detection, serta menggunakan metode transformasi hough untuk mendeteksi garis lurus [3] dan transformasi hit or miss untuk mengenali pola karakter [4].

Peneletian mengenai pendeteksian posisi nomor kendaraan sudah dilakukan oleh peneliti-peneliti sebelumnya. Metode-metode dan objek-objek citra yang digunakan juga beragam. Penelitian ini merupakan pengembangan penelitian yang dilakukan oleh I Dewa Gede Aditya Pemayun dan Widyadi Setiawan. Peneliti tersebut meneliti mengenai pendeteksian posisi plat nomor kendaraan menggunakan metode transformasi hough. Pengembangan dipenelitian ini adalah menambahkan metode transformasi hit or miss dalam proses akhir pendeteksian posisi plat nomor kendaraan $[5,6]$.

\section{METODE PENELITIAN}

Objek citra yang diambil berupa sepeda motor ataupun mobil. Didalam objek citra memuat satu atau dua plat nomor kendaraan, baik itu objek yang terdiri atas satu motor, satu mobil, dua sepeda motor, ataupun dua mobil. Pengambilan obyek citra dicontohkan pada Gambar 1.

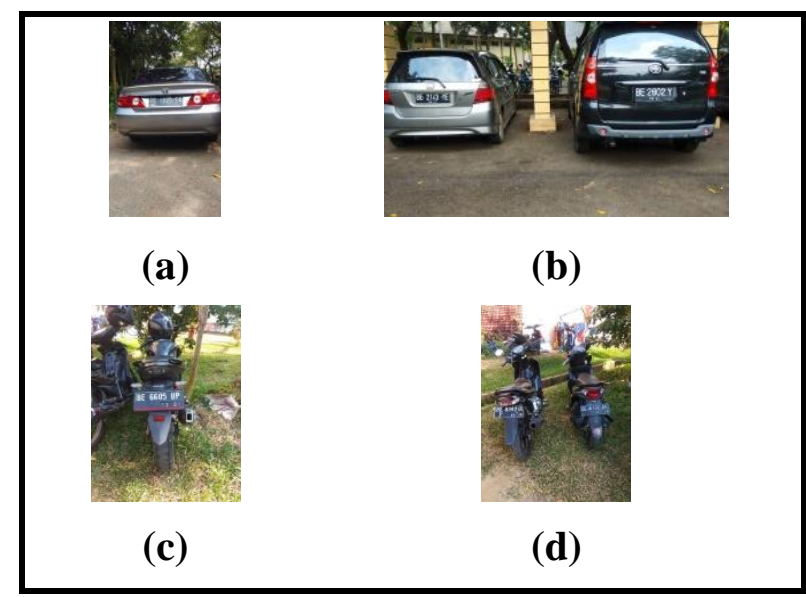

Gbr 1. (a) Obyek Citra Memuat Satu Mobil, (b) Obyek Citra Memuat Dua Mobil, (c) Obyek Citra Memuat Satu Motor (d) Obyek Citra Memuat Dua Motor

\section{A. Perancangan Sistem}

Perancangan sistem ditunjukkan pada Gambar 2. Sistem yang dirancang merupakan sistem GUI Matlab yang diharapkan mampu mendeteksi posisi plat nomor kendaraan. Didalam sistem, terdapat beberapa pilahan fitur seperti pembacaan citra, pengkonversian citra menjadi aras keabuan, pengubahan citra menjadi binerisasi, pengubahan kartesian menjadi polar, pembentukan garis lurus, dan pemotongan citra. Selain itu diberikan tiga nilai threshold untuk kesensitivan pendeteksian garis lurus. Nilai threshold tersebut adalah $0,7,0,8$ dan 0,85 .

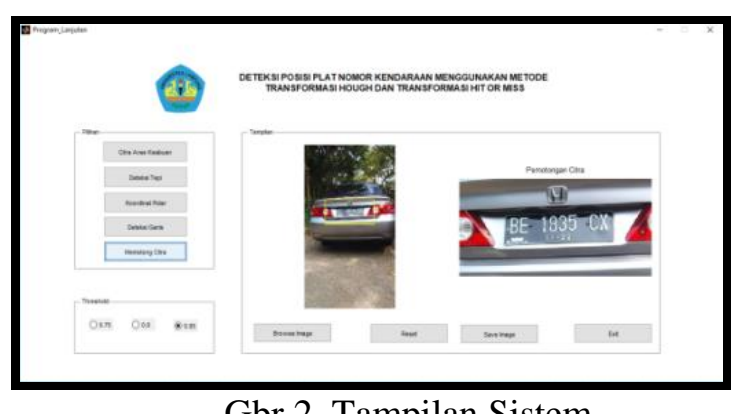

Gbr 2. Tampilan Sistem

\section{B. Pengolahan Awal Cira}

Pengolahan awal yang dilakukan pada sistem ini adalah pembacaan citra. Berkas citra yang hanya dapat dPibaca berformat .jpg. Setelah pembacaan citra, lalu dilanjutkan dengan pengskalaan ukuran citra dengan tujuan agar citra masukan memiliki ukuran yang sama saat diolah oleh sistem. Citra hasil penskalaan akan dikonversikan menjadi citra aras keabuan. Tujuannya adalah untuk mengurangi beban komputasi nilai citra dari 3 layer menjadi 1 layer. Setelah dilakukan penkonversian citra menjadi aras keabuan, dilanjutkan dengan pengkonversian citra menjad binerisasi dan kemudian dilanjutkan dengan deteksi tepi. Deteksi tepi yang digunakan adalah deteksi tepi canny.

\section{Proses Transformasi Hough}

Proses ini diawali dengan memberikan nilai threshold sistem. Nilai threshold adalah nilai tingkat kesensitivan sistem. Semakin kecil nilai threshold maka semakin banyak garis lurus yang terdeteksi, sedangkan semakin besar nilai threshold maka sedikit garis lurus yang terdeteksi. Selain itu juga, semakin kecil nilai threshold maka komputasi akan semakin lambat, sedangkan apabila nilai 
threshold semakin besar maka semakin cepat pula nilai komputasinya. Rentang nilai threshold berada diantara 0 hingga 1 , namun sistem ini memberikan 3 nilai threshold yaitu $0,75,0,8$, dan 0,85 . Sebab nilai tersebut merupakan nilai yang memliki hasil deteksi lumayan baik dan waktu komputasi yang cukup cepat.

Setelah diberikan nilai threshold, program akan mengubah citra dari koordinat kartesian menjadi koordinat polar. Nilai koordinat polar menjadi acuan untuk mendeteksi dan membangun deteksi garis lurus. Nilai koordinat merupakan titik garis lurus. Satu citra masukan mampu menghasilkan beribu-ribu garis lurus. Dari beberapa garis lurus yang terdeteksi merupakan kandidat posisi plat nomor kendaraan. Garis lurus hasil pendeteksian ditunjukkan pada Gambar 3(a) dan (b).

Setiap pendeteksian garis lurus, program akan memotong citra dari titik garis citra. Pemotongan citra dilakukan sebanyak dua kali dengan perhitungan panjang 400 piksel dikali 250 piksel. Pemotongan pertama dilakukan dari titik garis terdeteksi mengarah kebawah, kemudian pemotongan kedua dilakukan dari titik garis terdeteksi mengarah keatas. Sehingga satu titik garis akan menghasilkan dua gambar. Posisi titik garis hasil deteksi transformasi hough ditunjukkan Gambar 3.(a) dan (b). Hasil pemotongan ditunjukkan Gambar 3(c) dengan kotak berwarna kuning dan biru. Pemotongan dari titik garis mengarah keatas ditunjukkan dengan kotak berwarna kuning, sedangkan pemotongan dari titik garis mengarah kebawah ditunjukkan dengan kotak berwarna biru.

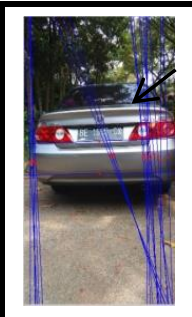

(a)

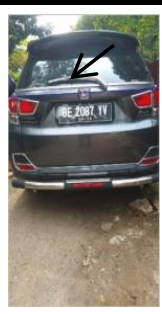

(b)

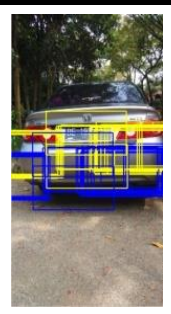

(c)

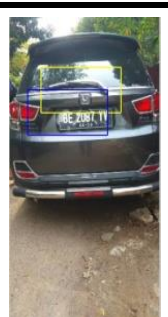

(c)
Gbr .3 (a) Titik Garis dibawah Plat (b) Titik Garis di atas Plat (c) Hasil Pemotongan

\section{Pengolahan Akhir Citra}

Setelah pendeteksian garis lurus dan pemotongan citra, dilanjutkan dengan pengenalan pola karakter menggunakan transformasi hit or miss. Karakter yang diajukan untuk dikenali adalah karakter "B". Karakter ini dipilih karena hampir semua sempel data pengujian memiliki karakter "B". Penelitian ini memberikan batasan masalah bahawa citra masukan hanya terkhusus kendaraan bermotor yang memiliki plat nomor kendaraan berawalan karakter "B".

Target karakter yang ingin dideteksi oleh transformasi hit or miss ditunjukkan pada Gambar 4. Target tersebut beresolusi $29 \times 15$ piksel dan ukuran tersebut sudah disesuaikan dengan data hasil yang akan dideteksi.

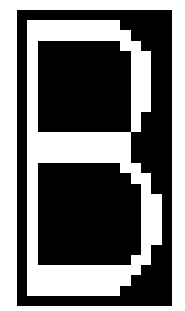

Gbr 4. Target Karakter

Citra hasil pemotongan sebelumnya diubah kebentuk deteksi tepi dan binerisasi kembali, guna memperoleh bentuk pola karakter yang lebih jelas. Selanjutnya proses yang dilakukan adalah proses dilasi. Tujuannya adalah untuk mempertegas garis tepi citra karena pengaruh penambahan citra. Proses transformasi hit or miss diawali dengan proses dilasi. Proses dilasi merupakan proses penambahan piksel dari elemen penstruktur. Elemen penstruktur yang digunakan adalah matrik $2 \times 2$ bernilai 1 . Setelah dilakukan proses dilasi, lalu dilanjutkan dengan menginputkan target karakter seperti Gambar 4. Target karakter bertindak sebagai elemen penstruktur untuk proses erosi, sehingga hasil proses dilasi akan dierosikan dengan target karakter. Pada program sistem, hasil proses erosi divariabelkan dengan G. Proses erosi dikerjakan kembali dengan menegasikan hasil proses dilasi dan menegasikan target karakter. Erosi yang kedua divariabelkan dengan G1 dan dilanjutkan dengan melakukan logika AND diantara variabel $G$ dan variabel G1. 
Proses akhir dari transformasi hit or miss adalah penyeleksian kotak. Seleksi dimulai dengan menghitung jumlah piksel yang terkandung didalam citra hasil proses transformasi hit or miss. Posisi plat nomor kendaraan yang akan terseleksi adalah citra yang memuat piksel lebih dari 2000 piksel dan citra yang berhasil dikenali karakter Bnya. Hasil seleksi kotak ditunjukkan Gambar 5(a) dan (b) dengan kotak berwarna merah.

Setelah berhasil menyeleksi kotak oleh transformasi hit or miss, dilanjutkan dengan eleminasi kotak yang tidak terseleksi. Kotak yang terseleksi akan dipotong dan dinormalisasikan guna terlihat lebih jelas dan tegas. Kotak yang telah dipotong dan dinormalisasikan ditunjukkan pada gambar 6(a) dan (b).

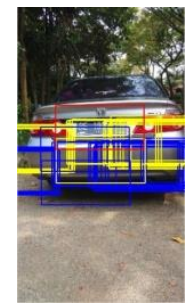

(a)

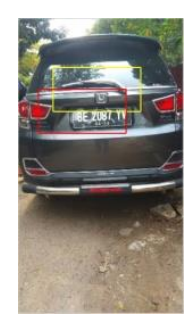

(b)
Gbr 5. Hasil seleksi kotak dengan warna merah

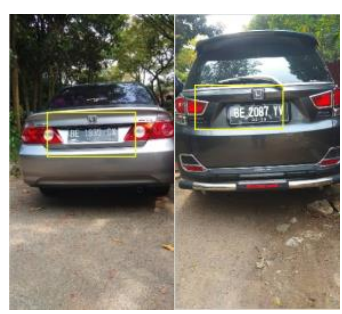

(a)

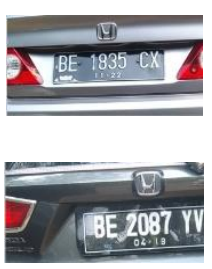

(b)
Gbr 6. (a) Kotak yang dipotong (b) Kotak yang dinormalisasi

\section{E. Keefektifan Sistem}

Keefektifan sistem dapat diukur dengan perhitungan terhadap nilai perolehan (recall), nilai ketepatan (precision) dan F-Value. Precision adalah tingkat ketepatan antara informasi yang diminta dengan jawaban yang diberikan oleh sistem. Untuk penelitian ini, informasi yang diminta adalah plat nomor kendaraan. Recall adalah tingkat keberhasilan sistem dalam menemukan informasi secara tepat. Untuk penelitian ini, informasi secara tepat adalah posisi plat secara utuh.

Perhitungan untuk recall, precesion, dan F-Value dinyatakan menggunakan persamaan 1, 2 dan 3.

$$
\begin{aligned}
& \text { Recall }=\frac{N_{T P}}{N_{T P}+N_{F N}} X 100 \% \\
& \text { Precision }=\frac{\mathbb{N}_{T P}}{\mathbb{N}_{T P}+\mathbb{N}_{F P}} X 100 \% \\
& F=2 \frac{\text { Recall } x \text { Precision }}{\text { Recall }+ \text { Precision }}
\end{aligned}
$$

Tahap perhitungan recall, precision dan F-Value ditunjukkan pada Gambar 7. Dimana $N_{T P}$ adalah jumlah piksel pada daerah TP (True Positive), $N_{F P}$ adalah jumlah piksel pada daerah FP (False Positive) dan $N_{F N}$ adalah jumlah piksel pada daerah FN (False Negative). Pada Gambar 7(d), daerah TP ditunjukkan dengan warna hitam; daerah FP ditunjukkan dengan warna biru; daerah TN (True Negative) ditunjukkan dengan warna kuning; dan daerah FN ditunjukkan dengan warna merah.

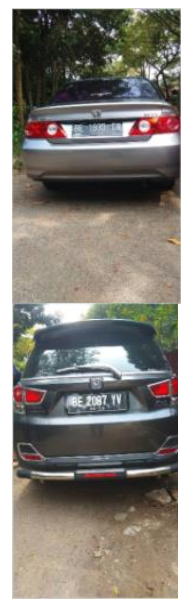

(a)

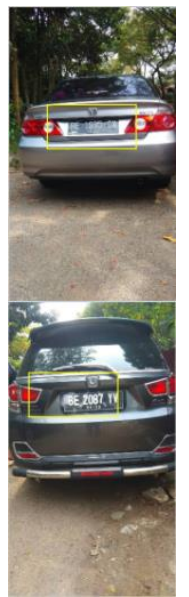

(b)

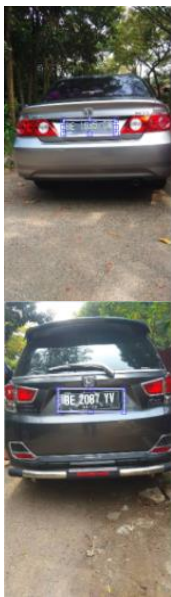

(c)

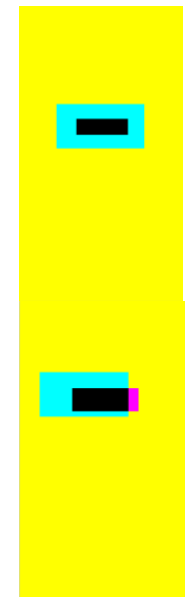

(d)
Gambar 7. (a) Citra Asli (b) Deteksi Kotak Sistem (c) Deteksi Kotak Sebenarnya (d) Gabungan Deteksi Kotak Sistem dan Kotak Sebenarnya

\section{HASIL DAN PEMBAHASAN}

Pengujian sistem menggunakan 50 sampel data. Data pengujian diambil dengan 2 ukuran, yaitu ukuran pertama beresolusi 960 x 1706 piksel dengan kecepatan 24 fps dan ukuran kedua berukuran 1108 x 1477 piksel dengan kecepatan pengambilan $24 \mathrm{fps}$. 
Data uji ukuran pertama berjumlah 25 data dan data uji ukuran kedua berjumlah 25 data. Data uji diambil dilingkungan Jurusan Teknik Elektro, Universitas Lampung.

Memuat hasil-hasil yang diperoleh beserta analisisnya.

Hasil pengujian sistem terbagi atas 3 bagian yakni pengujian sistem dengan nilai threshold 0,75 , pengujian sistem dengan nilai threshold 0,8 dan pengujian sistem dengan nilai threshold 0,85 . Hasil pengujian sistem ditunjukkan pada Tabel 1, Tabel 2 dan Tabel 3 .

Keberhasilan sistem banyak terjadi pada sempel data dengan gambar 1 mobil. Citra dengan gambar 1 mobil mampu terbaca dengan baik oleh dua metode yang diusulkan. Keberhasilan sistem juga dipengaruhi oleh faktor eksternal, seperti waktu pemotretan, intensitas cahaya, dan posisi pemotretan. Waktu pemotretan di pagi hari akan memberikan hasil gambar dengan intensitas cahaya yang cukup baik, sehingga intensitas cahaya yang terkandung didalamnya tidak tinggi ataupun lemah. Posisi pemotretan seperti landscape atau potrait juga mempengaruhi hasil pengujian sistem.

Tabel 1. Tingkat Keberhasilan Sistem

\begin{tabular}{ccc}
\hline $\begin{array}{c}\text { Jumlah } \\
\text { Data }\end{array}$ & Threshold & $\begin{array}{c}\text { Keberhasilan Sistem } \\
(\%)\end{array}$ \\
\hline 50 & 0,75 & 76 \\
& 0,8 & 72 \\
& 0,85 & 48 \\
\hline
\end{tabular}

Tabel 2. Hasil Pengujian Terhadap Ukuran Data

\begin{tabular}{cccc}
\hline $\begin{array}{c}\text { Juml } \\
\text { ah } \\
\text { Data }\end{array}$ & $\begin{array}{c}\text { Ukuran } \\
\text { Data }\end{array}$ & $\begin{array}{c}\text { Thresh } \\
\text { old }\end{array}$ & $\begin{array}{c}\text { Rata-rata } \\
\text { Keberhasilan } \\
(\%)\end{array}$ \\
\hline 25 & $960 \times$ & 0,75 & 80 \\
& 1706 & 0,8 & 76 \\
& & 0,85 & 44 \\
25 & $1108 \times$ & 0,75 & 48 \\
& 1477 & 0,8 & 48 \\
& & 0,85 & 52 \\
\hline
\end{tabular}

Tabel 3. Recall, Precission, dan F-Value

\begin{tabular}{|c|c|c|c|c|}
\hline \multirow{2}{*}{$\begin{array}{c}\text { Jumlah } \\
\text { Data }\end{array}$} & \multirow[t]{2}{*}{ Threshold } & \multicolumn{3}{|c|}{ Hasil Evaluasi } \\
\hline & & $\begin{array}{c}\text { Rata- } \\
\text { rata } \\
\text { recall } \\
(\%)\end{array}$ & $\begin{array}{c}\text { Rata-rate } \\
\text { precisior } \\
(\%)\end{array}$ & $\begin{array}{c}\text { Rata- } \\
\text { rata } \\
\text { F- } \\
\text { Value } \\
(\%)\end{array}$ \\
\hline \multirow[t]{3}{*}{50} & 0,75 & 54 & 14 & 22 \\
\hline & 0,8 & 50 & 14 & 21 \\
\hline & 0,85 & 40 & 12 & 18 \\
\hline
\end{tabular}

Pengujian yang tidak berhasil dikarenakan dua hal, pertama, proses pendeteksian garis lurus oleh transformasi hough tidak menyinggung posisi plat nomor kendaraan, sehingga posisi plat nomor kendaraan tidak terdeteksi. Kedua, pengenalan karakter " $\mathrm{B}$ " tidak berhasil dilakukan oleh transformasi hit or miss. Gagalnya pengenalan tersebut disebabkan kurang tegasnya karakter "B" dalam bentuk binerisasi sehingga transformasi hit or miss tidak mampu bekerja secara optimal. Penyebab lain gagalnya pengenalan karakter "B" adalah hilangnya satu piksel dalam karakter sehingga menggangu proses pengenalan pola oleh transformasi hit or miss.

\section{KESIMPULAN}

Setelah dilakukan pembuatan, pengujian dan analasi, dapat ditarik kesimpulan bahwa sistem ini berhasil mendeteksi posisi plat nomor kendaraan dengan tingkat keberhasilan $76 \%$ untuk nilai threshold $0,75,72 \%$ untuk nilai threhold 0,8 dan $48 \%$ untuk nilai threshold 0,85 . Selain itu sistem juga berhasil menemukan informasi posisi plat nomor kendaraan secara tepat dengan nilai rata-rata recall sebesar 54\% untuk nilai threshold 0,75 , $50 \%$ untuk nilai threshold 0,8 dan $40 \%$ untuk nilai threshold 0,85 . Sistem juga berhasil memunculkan dan mempertegas posisi plat nomor kendaraan dengan nilai rata-rata precision sebesar $14 \%$ untuk nilai threshold $0,75,14 \%$ untuk nilai threshold 0,8 dan $12 \%$ untuk nilai threhsold 0,85 . Kegagalan sistem banyak terjadi pada citra yang terdiri dari 2 motor dan 2 mobil. Kegagalan sistem dipengaruhi oleh bentuk kualitas citra, tingkat kecerahan citra, posisi kemiringan citra, 
keberagaman bentuk citra dan kurang tegasnya karakter " $\mathrm{B}$ " dalam bentuk binerisasi.

Untuk dapat memperbaiki kelemahankelemahan pada sistem, disarankan untuk melakukan pengembangan atau perbaikan sistem dengan cara mengaplikasikan sistem dalam kehidupan nyata secara real time dan membuat sistem dengan lebih handal dan dengan waktu yang lebih cepat.

\section{UCAPAN TERIMA KASIH}

Terima kasih kepada Fakultas Teknik Universitas Lampung yang mendanai penelitian ini melalui DIPA Fakultas Teknik.

\section{REFERENSI}

[1] Para Kontributor Wikipedia. ( 2004, February). Tanda nomor kendaraan bermotor. Retrieved from Wikipedia website

http://id.wikipedia.org/wiki/Nomor_polis i.

[2] Samijayani, O.N. (2012) Penerapan Metode Simulasi Pra-Praktikum Menggunakan Graphic User Interface (GUI) dan FDATOOL, MATLAB, Jakarta: Universitas Al Azhar Indonesia.

[3] Sa'diyah, H. (2011), Aplikasi Transformasi Hough untuk Deteksi Garis Lurus. (Skripsi). Universitas Diponegoro, Semarang.

[4] Kadir, A. (2013), Teori dan Aplikasi Pengolahan Citra, Yogyakarta: Andi.

[5] Setiawan, W., Asri, S. A. (2015) Penerapan Transformasi Hough pada Deteksi Lokasi Plat Nomor Pada Citra Kendaraan, Matrix, 5(02), 41-46.

[6] Pemayun, I D. G. A., Setiawan, W., Indra, N. ER. (2015) Analisis Sistem Pendeteksi Posisi Plat Kendaraan dari Citra Kendaraan, E-Journal SPEKTRUM, 2(02), 2, 61-67. 